\title{
Export competitiveness of dairy products on global markets: The case of the European Union countries
}

\author{
Š. Bojnec ${ }^{* 1}$ and I. Fertő†‡ \\ *University of Primorska, Faculty of Management, Cankarjeva 5, SI-6104 Koper, Slovenia \\ †Corvinus University, Fővám tér 8, H-1093 Budapest, Hungary \\ łInstitute of Economics, Hungarian Academy of Sciences, Budaörsi u. 45, H-1112 Budapest, Hungary
}

\section{ABSTRACT}

This paper analyzed the export competitiveness of dairy products of the European Union (EU) countries (EU-27) on intra-EU, extra-EU, and global markets, using the revealed comparative advantage index over the 2000-2011 period. The results indicated that about half of the EU-27 countries have had competitive exports in a certain segment of dairy products. The results differed by level of milk processing and for intra-EU and extra-EU markets, and did so over the analyzed years. Belgium, Denmark, France, Ireland, and the Netherlands are old EU-15 countries with competitive dairy exports (from the lowest to the highest according to the level of milk processing). The majority of the new EU-12 countries have faced difficulties in maintaining their level of export competitiveness, at least for some dairy products and market segments. The more competitive EU-12 countries in dairy exports were the Baltic States (Estonia, Latvia, and Lithuania) and Poland. The duration of export competitiveness differed across the dairy groups of products according to the level of milk processing, indicating the importance of dairy chain product differentiation for export competitiveness and specialization. The export competitiveness of the higher level of processed milk products for final consumption can be significant for export dairy chain competitiveness on global markets.

Key words: global export competitiveness, duration analysis, dairy products differentiation, European Union

\section{INTRODUCTION}

The complexity of national and global dairy chain structures and possible changes in export competitiveness are of increasing private sector and public policy concern (Pinior et al., 2012). The dairy industry plays

\footnotetext{
Received November 12, 2013.

Accepted June 14, 2014.

${ }^{1}$ Corresponding author: stefan.bojnec@fm-kp.si or stefan.bojnec@ siol.net
}

a more important role in the food industry in the European Union (EU) countries than it does in the United States in terms of share of turnover or value added in production (Tacken et al., 2009). In addition, exports of dairy products have considerable importance within the total agri-food trade for almost all of the EU-27 countries and in the global dairy trade (FAO, 2013).

Dairy chain export competitiveness on global markets is a crucial factor for the dairy sector's economic sustainability in the global marketing environment. Empirical studies have highlighted the weakness of the competitiveness in the EU dairy industry, with particular emphasis on the role of processed dairy products for the sector's competitiveness and economic sustainability, which has increased at the expense of bulk raw milk products (Drescher and Maurer, 1999; Kirner, 2005; Hockmann et al., 2007; Bojnec and Fertő, 2008; Tacken et al., 2009). In relation to the recent economic crisis, the EU dairy industry is confronted with high food prices on global markets; this has put the agri-food industry back at the top of the agenda of international trade policy forums.

The aim of this paper was to assess the export competitiveness of the dairy industry in the EU-27 countries on intra-EU and extra-EU markets during the 2000-2011 period. More specifically, its aim was to identify the most competitive EU-27 countries in the dairy industry and to evaluate the stability and the duration of export competitiveness for dairy products.

This paper contributes to the existing literature in at least 3 significant directions. First, it contributes to a better understanding of the level, composition, and evolution of export competitiveness in the dairy industry at various levels of the dairy supply chain for the analyzed EU-27 countries in intra-EU and extraEU markets. Second, it compares the competitiveness of the EU-27 countries in the dairy industry over the 2000-2011 period, which covers the enlargements on May 1, 2004, with 10 new member states (Cyprus, the Czech Republic, Estonia, Hungary, Latvia, Lithuania, Malta, Poland, Slovakia, and Slovenia) and on January 1, 2007, with an additional 2 new member states 
(Bulgaria and Romania). Finally, it analyzes the evolution, stability, and duration of the EU-27 countries' competitiveness according to countries, intra-EU versus extra-EU market segments, and stages of dairy supply chain.

\section{MATERIALS AND METHODS}

\section{Estimation Framework}

Previous studies have analyzed the different production and specific trade structures of dairy products (Dunnett, 1933; Bailey, 2004; Van der Straeten et al., 2009; Pinior et al., 2012; Cecchinato, 2013). Dairy product competitiveness can be determined by different factors, such as milk quality assurance (Liebe and Schams, 1998), dairy cow diseases (Losinger, 2005), and various determinants in dairy supply chain management (Roupas, 2008). Dairy market deregulation creates pressures on lowering price supports in dairy product supply chains. In the increased competition on global dairy markets, the crucial issues are related to international competitiveness and marketing on global markets (Novakovic and Thompson, 1978; Marchant and Neff, 1995; Barney and Smith, 1998; Stukenberg and Blayney, 2006). Therefore, questions of comparative advantages among global dairy exporters, such as the United States, New Zealand, Australia (Buxton and Frick, 1976), and the enlarged EU-27 countries, on global markets are of particular research and policy relevance for politically and economically sensitive dairy product reforms in several countries (Suzuki and Kaiser, 2005), as well as dairy supply chain management.

Competitiveness can be analyzed at 3 different levels: the national (i.e., macroeconomic) level, the industrial (i.e., branch) level, and the firm (i.e., microeconomic) level. Another aspect of competitiveness exists with regard to the spatial or geographical dimension of the investigation, comparing enterprises or trade flows within a region of a particular country or between countries. The focus of this paper is on the competitiveness at the dairy branch level on intra-EU and extra-EU market segments.

A country's ability to compete in intra-EU and extraEU markets depends on its comparative advantages. According to Balassa (1965), the nature of revealed comparative advantages for the dairy group of products according to the level of milk processing is investigated by using the methodological approach, which is widely used in empirical trade literature to identify a country's weak and strong export sectors. The revealed comparative advantage (RCA) index, as introduced by Balassa (1965), is defined as follows:

$$
\mathrm{RCA}=\left(\mathrm{X}_{i j} / \mathrm{X}_{i m}\right) /\left(\mathrm{X}_{w j} / \mathrm{X}_{w m}\right),
$$

where $\mathrm{X}$ represents exports, $i$ is a country, $j$ is a commodity, $m$ is a set of commodities, and $w$ is a set of countries in the world. Despite some critiques of the RCA index as an export specialization index - such as the asymmetric value problem and the problem with logarithmic transformation (De Benedictis and Tamberi, 2004), the importance of the simultaneous consideration of the import side (Vollrath, 1991), and the lack of a sound theoretical background, which is provided by Costinot et al. (2012) and Leromain and Orefice (2013) - the RCA index remains a popular tool for analyzing export competitiveness in empirical trade literature. The RCA index is based on observed export patterns. It is computed as the share of dairy products $j$ in country i's exports, divided by the share of these products in global exports; it measures the specialization of a country in some product (or group of products) relative to the global level; that is, to the share of this (these) product(s) in global trade. If $\mathrm{RCA}>1$, then a country's dairy product comparative advantage on the global market is confirmed. In other words, the country is relatively more specialized in terms of exports for a given group of dairy products. In this paper, $\mathrm{X}_{i j}$ describes individual EU-27 countries' $i$ exports for a particular dairy product $j$ to the global markets, whereas $\mathrm{X}_{i m}$ is the total exports of individual EU-27 countries' $i$ to global markets; $\mathrm{X}_{w j}$ denotes the global exports for a given dairy product $(j)$; and $\mathrm{X}_{w m}$ denotes total global exports, which are used as a benchmark of comparison.

The EU-27 dairy market is known to be highly protected from foreign competition, leading to greater export performance of EU countries on the domestic (intra-EU) market compared with the extra-EU market. Therefore, we used 2 alternative benchmarks: the intra-EU-27 market and the extra-EU market, calculated as global exports minus EU-27 exports for each element in the equation of RCA indices.

The RCA can be equal to 1 (no specialization or no disadvantage when the country's exports structure reflects the exact structure of global trade), greater than 1 (the country has a comparative advantage in the concerned product), or less than 1 (the country has a comparative disadvantage in the concerned product). These boundaries are consistent with a theoretical interpretation appropriate for cross-country comparisons between $\mathrm{RCA}<1$ and $\mathrm{RCA}>1$, but the content of the categories can vary from year to year. The usual interpretation of an RCA index is that it identifies the extent to which a country has a comparative (dis)advantage with a given product. However, it does not necessarily mean that the RCA index can be interpreted as a cardinal index. Fertö and Hubbard (2003) show that the RCA index performs better as an ordinal or dichotomous measure. 
The stability of the RCA indices for each EU-27 country for specific dairy products was investigated in 2 steps. First, Markov transition probability matrices were used to identify the persistence in the evolution and mobility of RCA indices. Dairy products were classified into 2 categories: dairy products with revealed comparative disadvantages $(\mathrm{RCA}<1)$ and dairy products with revealed comparative advantages $(\mathrm{RCA}>1)$. Let $P_{b}^{a}$ denote a one-step transition probability, which is the probability that, for yearly observations, the next period's RCA index of a particular product and country falls into class $b$ with a revealed comparative advantage, given that this period's RCA index for that same product and country falls into class $a$ with a revealed comparative disadvantage. These probabilities can be estimated by counting the number of transitions out of and into each cell. The interpretation of persistence or mobility throughout the entire distribution of the RCA index can be easily studied by using a transition probability matrix. High values of the Markov transition probability matrix along the diagonal suggest high persistency, whereas high values for off-diagonal elements imply large mobility.

Second, the degree of mobility in the patterns of revealed comparative advantage can be summarized using an index of mobility. This formally evaluates the degree of mobility, in particular with regard to whether a country gains or loses its comparative advantage (i.e., its RCA becomes greater or lower than 1) throughout the entire distribution of RCA indices, and facilitates direct cross-country comparisons. The mobility index, $\boldsymbol{M}_{\mathbf{1}}$, following Shorrocks (1978), evaluates the trace (tr) of the Markov transition probability matrix. This $M_{1}$ index thus directly captures the relative importance of off-diagonal terms and can be shown to equal the inverse of the harmonic mean of the expected duration of remaining in a given cell:

$$
M_{1}=\frac{K-\operatorname{tr}(P)}{K-1},
$$

where $K$ is the number of classes (i.e., 2 classes in this paper), and $P$ is the Markov transition probability matrix. A higher value of $M_{1}$ indicates greater mobility [the upper limit is 2 in this paper, which is derived from the definition of $M_{1}$; if there is a $2 \times 2$ matrix and the values in diagonals are zero, i.e., $\operatorname{tr}(P)=0$, then $M_{1}$ $=(2-0) /(2-1)=2]$, with a value of zero indicating perfect immobility.

The next step to examine is the duration of comparative advantage. Calculating the duration then appears to be straightforward: it is simply the time (measured in years) that a product has maintained a comparative advantage without any interruption. Alternatively, ap- plying statistical techniques from survival analysis, the duration can be modeled as a sequence of conditional probabilities that a product's comparative advantage continues after $t$ periods, given that it has already survived for $t$ periods. Specifically, let $T$ be a random variable that denotes the length of a spell. Then, in discrete time, the survival function, $S(T)$, is defined as follows:

$$
S(T)=\operatorname{Pr}(T \geq t) .
$$

In empirical studies, the survival functions are estimated (in a nonparametric way) by computing the number of spells that survive (end) as a fraction of the total number of spells that are at risk after $t$ periods. More specifically, the duration of revealed comparative advantage $(\mathrm{RCA}>1)$ for each of the EU-27 countries is estimated by applying the nonparametric KaplanMeier product limit estimator (Cleves et al., 2004).

The Kaplan-Meier estimator of the hazard function is the fraction of spells that fail after $t$ periods of all spells that have survived $t$ periods. The survivor function is the share of spells that survives at time $t$, but this time is cumulative of all preceding time intervals. That is, if all spells survive and the ratio is 1, the survivor function is flat at this interval; otherwise, the function is stepwise declining.

Formally, the Kaplan-Meier estimator of the survival function is

$$
\hat{S}(t)=\prod_{t(i)<t} \frac{n_{j}-d_{j}}{n_{j}},
$$

where $n_{j}$ denotes the number of subjects at risk of failing at $t\left({ }_{j}\right)$, and $d_{j}$ denotes the number of observed failures. Given that many observations are censored, it is then noted that the Kaplan-Meier estimator is resistant to censoring and uses information from both censored and noncensored observations. It is possible that, in some cases, comparative advantages were dissolved and later re-established during the sample period. The episodes of uninterrupted comparative advantage are the primary unit of analysis.

Finally, whether export competitiveness is the same or varies between dairy products according to the level of milk processing is verified. Therefore, the Wilcoxon signed-rank test as a nonparametric statistical hypothesis test was applied for the equality of survival functions of RCA indices between various stages of the dairy supply chain.

\section{Data}

An empirical analysis of the RCA indices for dairy products was conducted for the EU-27 countries us- 
ing detailed trade data at the 6-digit World Customs Organization's Harmonized System (HS-6) level from the years 2000 to 2011. Dairy trade, as defined by the International Standard Industrial Classification (ISIC3112 ), contains 26 HS-6 dairy products. To obtain more information on the various stages of the dairy chain, the HS-6 code data were transformed into Broad Economic Classification system (BEC) data, which includes 4 main dairy chain product categories: BEC 22 $=$ industrial supplies not elsewhere specified; processed (containing 2 HS-6 code dairy products); BEC $112=$ primary mainly for household consumption (containing 5 HS-6 code dairy products); BEC $121=$ processed mainly for industry (containing 6 HS-6 code dairy products); and BEC 122 = processed mainly for household consumption (containing 13 HS-6 code dairy products). The UNSD (2013) concordance between the HS-6 codes and the BEC system and their product descriptions are used. In the Appendix, Table A1 lists the HS-6 code names of the dairy products included in each BEC classification. The UN Comtrade database (UNSD, 2013), with the World Integrated Trade Solution (WITS; http://wits.worldbank.org) software, is used in the RCA calculations for dairy products. Intra-EU trade is included, and comparisons are made between results, with and without intra-EU trade.

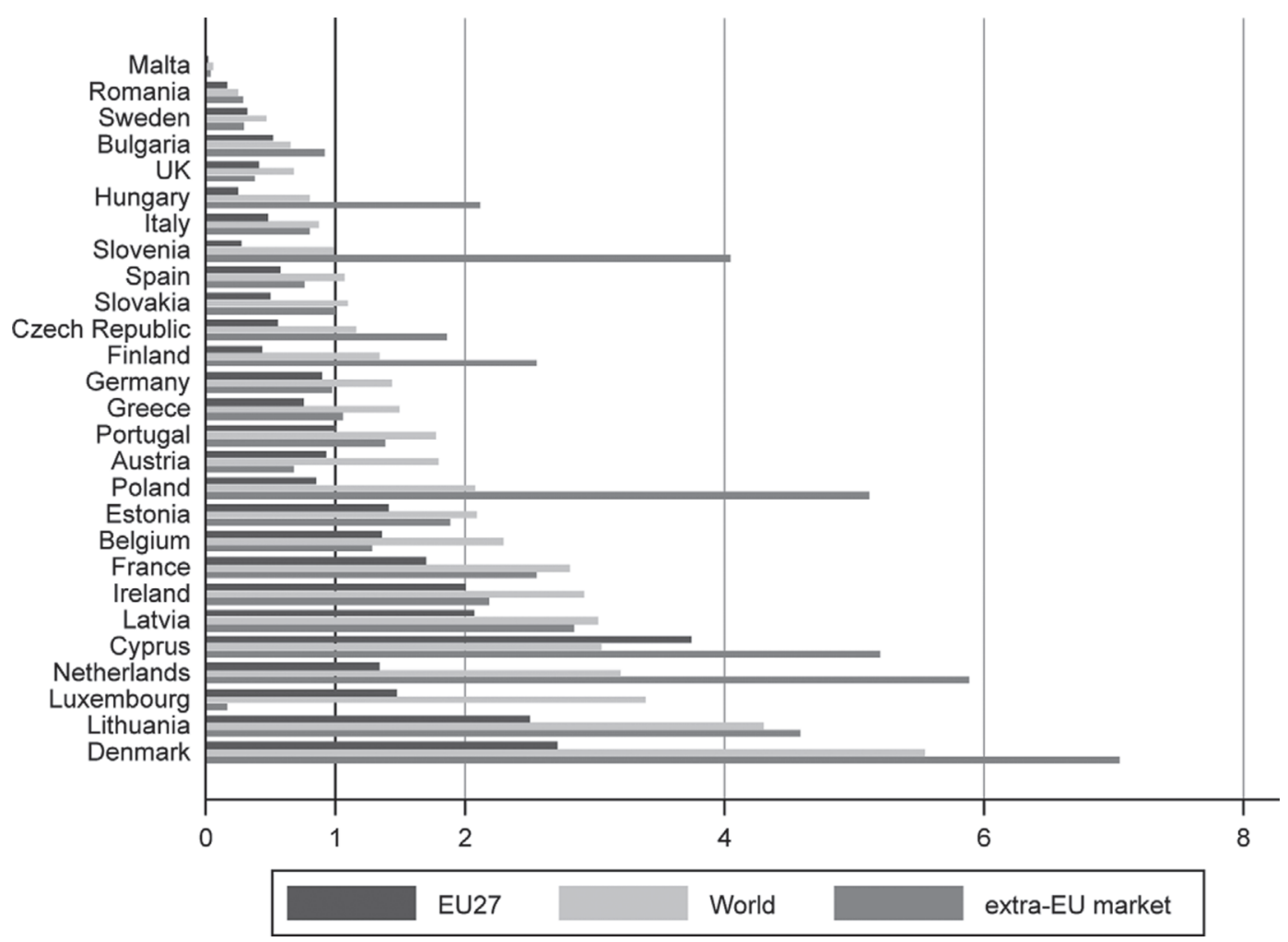

Figure 1. Mean values of revealed comparative advantage (RCA) indices for dairy products in the EU-27 countries from 2000 to 2011 . EU27 = intra-European Union (EU) market, and World = intra-EU and extra-EU markets. Source: Authors' calculations based on Comtrade database (UNSD, 2013) with World Integrated Trade Solution (WITS; http://wits.worldbank.org) software.

\section{RESULTS}

\section{RCA Indices}

The RCA indices for dairy products calculated for extra-EU markets were greater than those for the intraEU markets (Figure 1). The levels of the RCA indices for dairy products by the BEC dairy group of products and by the analyzed market segments for each of the EU-27 countries over the analyzed years (2000-2011) are available from the authors upon request. Among the outliers, we can find some EU-12 countries located near extra-EU markets: Cyprus in the Mediterranean region, Lithuania and Poland with the former Soviet Union markets, and Slovenia with the former Yugoslav republics. Latvia, Lithuania, the Netherlands, and Portugal were competitive on intra- and extra-EU markets. This was particularly so for Denmark and the Netherlands, from among the EU-15 countries. The Czech Republic, Finland, Greece, Hungary, Poland, Slovakia, and Slovenia were competitive only on the extra-EU markets; Luxembourg was so only on the intra-EU markets; Austria, Germany, and Spain were so only on the global market because of possible structural effects between uncom-
Belgium, Cyprus, Denmark, Estonia, France, Ireland, 


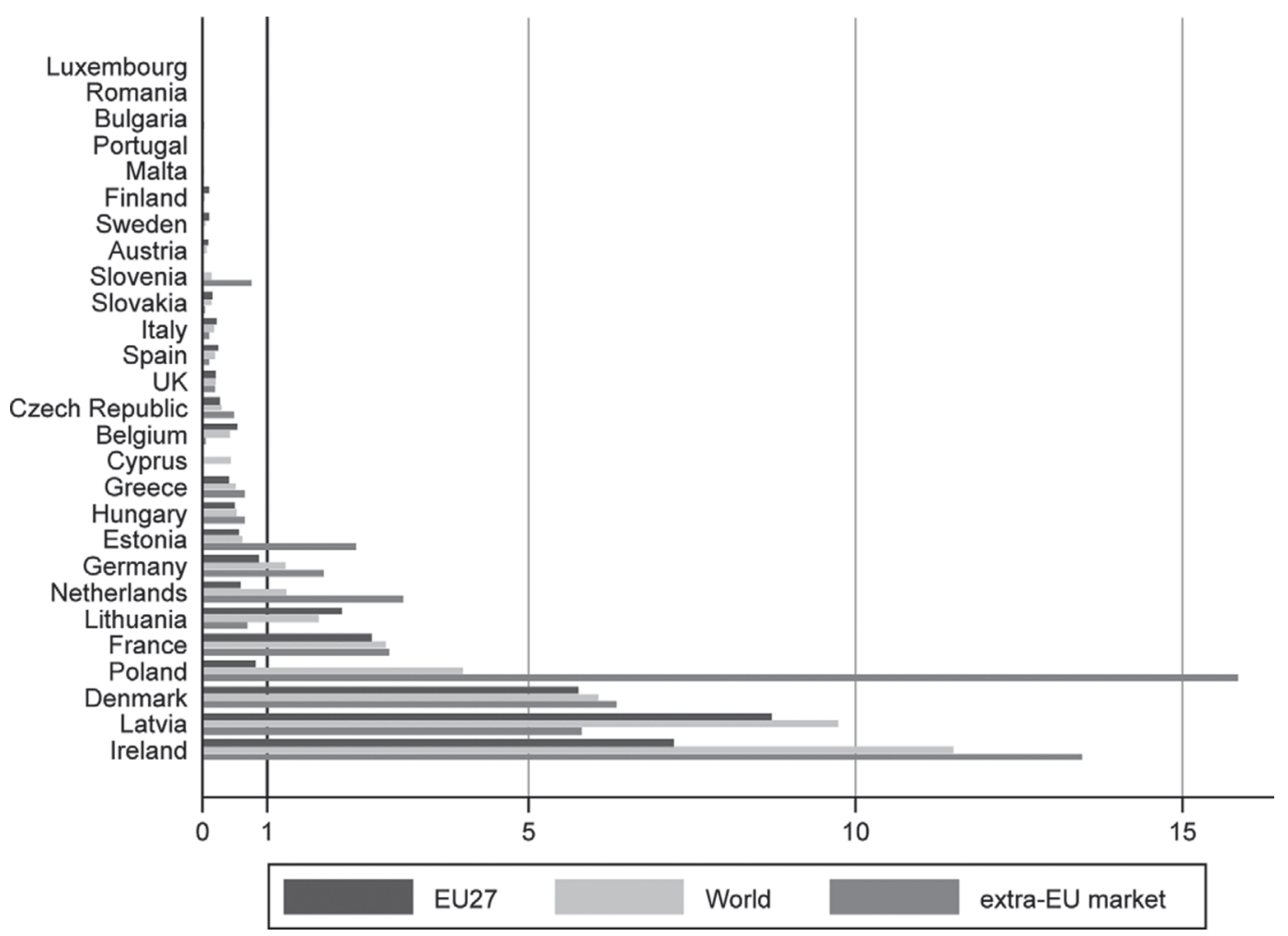

Figure 2. Mean values of revealed comparative advantage (RCA) indices for the Broad Economic Classification (BEC) 22: industrial supplies not elsewhere specified; processed in the EU-27 countries from 2000 to 2011 . EU27 = intra-European Union (EU) market, and World = intraEU and extra-EU markets. Source: Authors' calculations based on Comtrade database (UNSD, 2013) with World Integrated Trade Solution (WITS; http://wits.worldbank.org) software.

petitive intra- and extra-EU markets; Bulgaria, Italy, Malta, Romania, Sweden, and the United Kingdom (UK) were not competitive in any market segment.

To summarize, the results on the levels of the RCA indices for dairy products were mixed among the EU27 countries but generally supported the main finding that most of the EU-27 countries are competitive in exports of dairy products on the extra-EU and global markets. However, this export competitiveness is not homogeneous throughout all dairy groups of products according to the level of milk processing.

For the BEC 22, RCA > 1 was greater for extra-EU than for intra-EU markets for Denmark, France, and Ireland. In contrast, RCA $>1$ was greater for intraEU than for extra-EU markets for Latvia (Figure 2). The RCA > 1 was only for extra-EU, not for intra-EU, for Estonia, Germany, the Netherlands, and Poland. In contrast, RCA $>1$ was only for intra-EU, not for extra-EU, for Lithuania. Although these countries were competitive in BEC 22 exports in at least one of the market segments, the other two-thirds of the EU-27 countries revealed comparative disadvantages.

Most of the EU-27 countries were competitive in BEC 112 in at least one market segment: Estonia, France, Greece, Latvia, Lithuania, Portugal, and Spain were intra-EU and extra-EU competitive; Cyprus, the Czech Republic, Denmark, Finland, Hungary, Ireland, the Netherlands, Poland, Slovakia, and Slovenia were extra-EU competitive, but not intra-EU competitive; Austria, Belgium, Germany, and Luxembourg were intra-EU competitive, but not extra-EU competitive; Bulgaria, Italy, Malta, Romania, Sweden, and the UK were not competitive in any market segment (Figure 3 ).

In BEC 121, Belgium, Denmark, Estonia, France, Ireland, Latvia, Lithuania, the Netherlands, and Poland were competitive on the intra-EU and extra-EU markets; Bulgaria and Portugal were competitive only on the intra-EU markets, and the Czech Republic and Finland only on the extra-EU markets; Germany, Italy, and Luxembourg were competitive only on the global markets; Austria, Cyprus, Greece, Hungary, Malta, Romania, Slovakia, Slovenia, Spain, Sweden, and the UK were not competitive in any market segment (Figure 4).

The RCA for the BEC 122 on intra-EU and extra-EU markets consisted of Belgium, Cyprus (on the basis of the result for a single year), Denmark, Estonia, France, Ireland, Latvia, Lithuania, and the Netherlands; Luxembourg only on the intra-EU markets; Bulgaria, the Czech Republic, Finland, Germany, Hungary, Italy, and Poland only on extra-EU markets; Austria, Greece, 


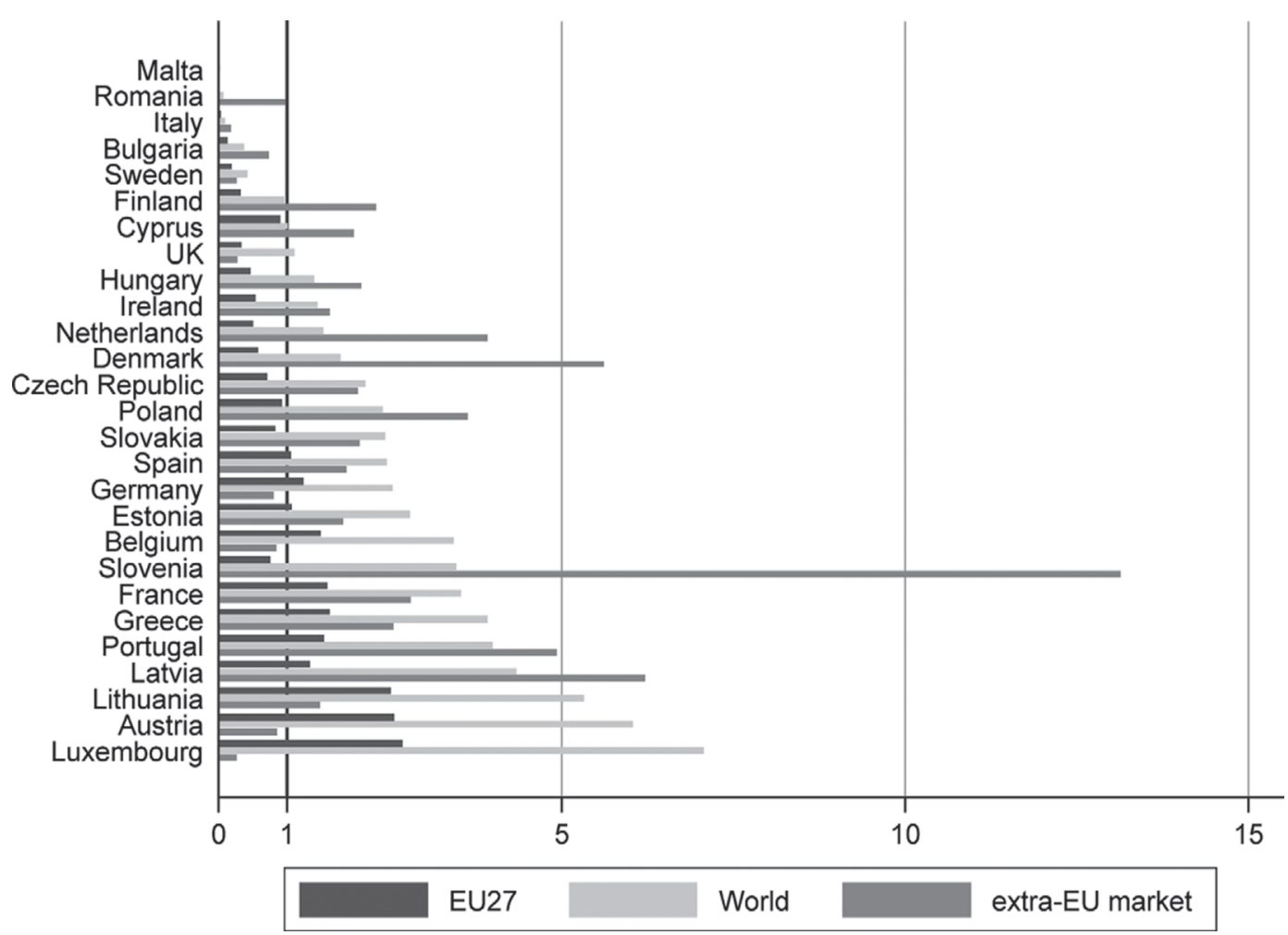

Figure 3. Mean values of revealed comparative advantage (RCA) indices for the Broad Economic Classification (BEC) 112: primary dairy products mainly for household consumption in the EU-27 countries from 2000 to 2011. EU27 = intra-European Union (EU) market, and World = intra-EU and extra-EU markets. Source: Authors' calculations based on Comtrade database (UNSD, 2013) with World Integrated Trade Solution (WITS; http://wits.worldbank.org) software.

Malta, Portugal, Romania, Slovakia, Slovenia, Spain, Sweden, and the UK were not competitive in any market segment (Figure 5).

To summarize, the unweighted mean values of RCA indices can be biased due to the fact that a country can export only some niche products that are competitive in all market segments. Most of the EU-27 countries have diverse product portfolios, which are less likely to survive the whole period. This can explain the heterogeneity of RCA indices for groups of dairy products according to the level of milk processing over time. Except for France and Latvia, which were competitive throughout the dairy chain in each of the market segments, Denmark, Ireland, and Estonia failed in a single product group, whereas Belgium, the Netherlands, and Lithuania failed in 2 stages of the dairy chain. When producing and exporting a wider product portfolio, the probability of losing the revealed comparative advantage can be a greater in a particular product group; therefore, most of the EU-27 countries need to specialize. This is in the spirit of both the Ricardian and the Hecksher-Ohlin-Samuelson models (also known as the factor endowment or the variable proportion model; Feenstra, 2004), which are based on the idea that there is a need to specialize.

\section{Mobility of the RCA Indices}

The degree of mobility in evolution of the RCA $<1$ and RCA $>1$ indices throughout the entire distribution of the RCA indices for dairy products of the EU-27 countries was estimated using the mobility index, $M_{1}$, based on the Markov transition probability matrices, using a 1-yr lag. For illustrative purposes, the Markov matrices for the EU-27 countries are presented as a single economic unit according to each market segment. Table 1 shows the low probability (ranging between 10 and $17.5 \%$ ) that dairy products with a revealed comparative disadvantage $(\mathrm{RCA}<1)$ might shift to a revealed comparative advantage $(\mathrm{RCA}>1)$. It is more likely that those products with an RCA $>1$ may move backward via a switch to an RCA $<1$ (between 18.3 and $26.1 \%$ ). The high values in the diagonals suggest considerable stability in the RCA indices.

The empirical results in Table 2 indicate relatively low mobility rates and thus relatively high stability in the RCA indices at the dairy product level by the EU-27 countries. Intra-EU mobility rates were generally slightly greater and thus relatively less stable than extra-EU mobility rates. For most of the EU-27 countries, their mobility rates on global markets were 


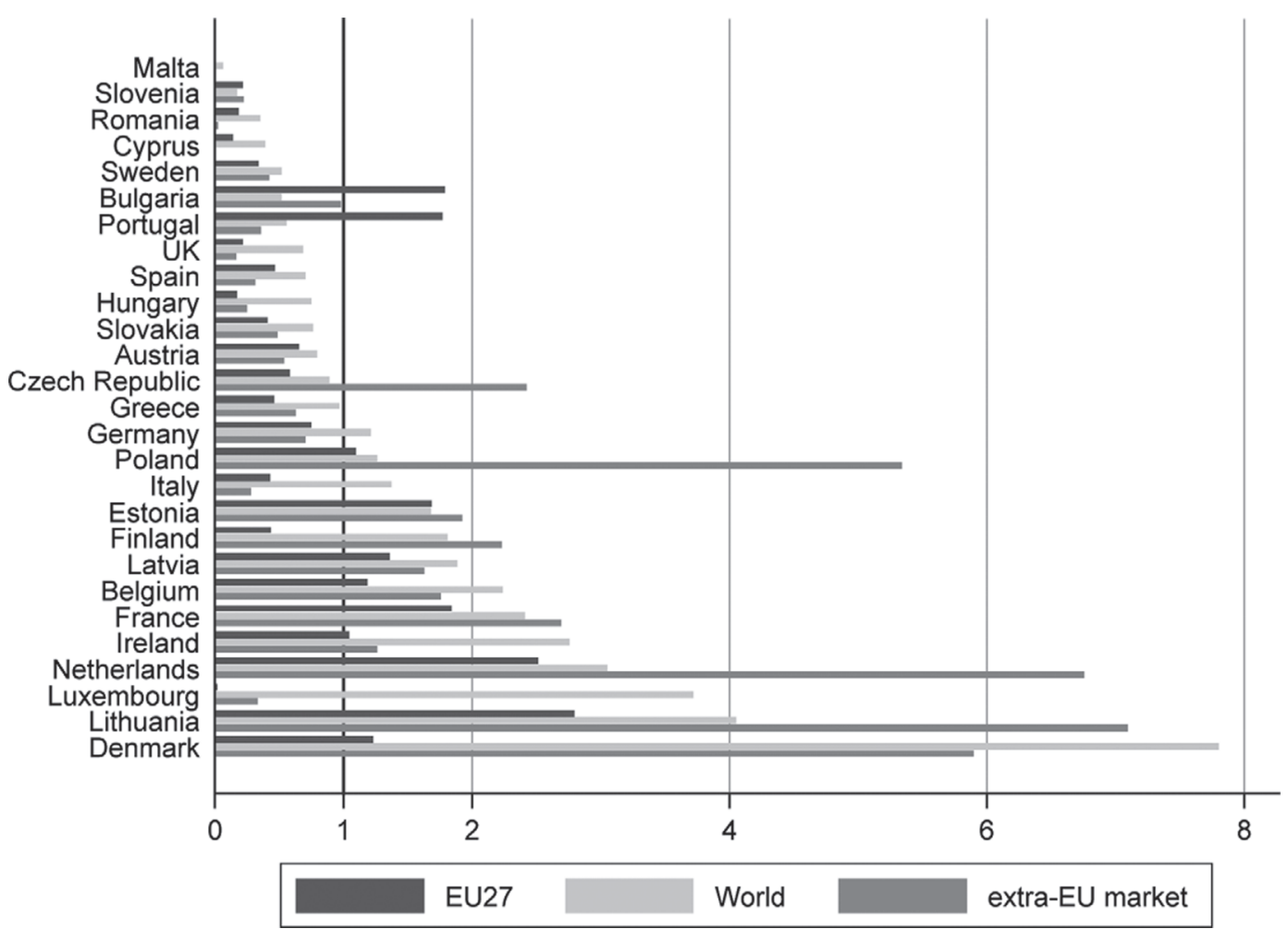

Figure 4. Mean values of revealed comparative advantage (RCA) indices for the Broad Economic Classification (BEC) 121: processed dairy products mainly for industry in the EU-27 countries from 2000 to 2011. EU27 = intra-European Union (EU) market, and World = intra-EU and extra-EU markets. Source: Authors' calculations based on Comtrade database (UNSD, 2013) with World Integrated Trade Solution (WITS; http://wits.worldbank.org) software.

lower and thus more stable than individual intra-EU or extra-EU mobility rates, suggesting switches between intra-EU and extra-EU dairy products' export competitiveness in the long term. Considering EU-27 countries' intra-EU and extra-EU mobility rates, the $M_{1}$ indices indicate rather high stability with relatively low mobility in evolutions throughout the entire distribution of the RCA indices for dairy products. This evolution indicates rather strong specialization patterns in the dairy production, processing, and marketing chain for dairy groups of products, regardless of the level of milk processing.

\section{Duration Analysis of the RCA >1}

Table 3 depicts the Kaplan-Meier survival rates for the duration analysis for dairy RCA $>1$ indices of the EU-27 countries for intra-EU, extra-EU, and global market segments for the final (i.e., 12th) analyzed year (2011) of the BEC dairy group of products. Furthermore, the Wilcoxon nonparametric test of equality of survival function across the BEC dairy group of products is estimated.

The survival rates for the dairy $\mathrm{RCA}>1$ indices, except for the intra-EU dairy exports, were highest for
France, Denmark, and the Netherlands. The duration of the RCA $>1$ indices for these 3 old EU-15 member states on intra-EU and global dairy markets is considerably longer than the duration for the dairy RCA > 1 indices for other old EU-15 and new EU-12 member states. Among the new EU-12 member states, the duration of the RCA > 1 index on the global dairy market was highest for Poland, Latvia, Lithuania, and Estonia.

For most of the EU-27 countries, the survival rates of the RCA > 1 indices in 2011 were very low or equal to zero in intra-EU dairy exports. This implies strong competition within the intra-EU dairy market. Among the outliers are Malta, Cyprus, and, to a lesser extent, Slovenia, throughout the dairy group of products, regardless of the level of milk processing.

The survival rates of the RCA $>1$ indices in yr 12 (2011) were higher in extra-EU dairy exports. Except for Slovakia, other EU-27 countries were also competitive in at least a single dairy group of products according to the level of milk processing. Therefore, most of the EU-27 countries are able to compete in dairy exports on extra-EU markets on a long-term basis.

Substantial differences can be seen in the survival rates according to the level of milk processing. Most of the EU-27 countries have experienced higher survival 
Table 1. Markov transition probability matrices for the world, intra-European Union (EU), and extra-EU markets ${ }^{1}$

\begin{tabular}{lcccccccc}
\hline & \multicolumn{2}{c}{ World } & & \multicolumn{2}{c}{ Intra-EU } & & \multicolumn{2}{c}{ Extra-EU } \\
\cline { 2 - 3 } $\mathrm{RCA}^{2}$ & $\mathrm{RCA}<1$ & $\mathrm{RCA}>1$ & & $\mathrm{RCA}<1$ & $\mathrm{RCA}>1$ & & $\mathrm{RCA}<1$ & $\mathrm{RCA}>1$ \\
\hline $\mathrm{RCA}<1$ & 90.0 & 10.0 & & 85.3 & 17.5 & & 85.3 & 14.7 \\
$\mathrm{RCA}>1$ & 18.9 & 81.1 & & 26.1 & 73.9 & & 18.3 & 81.8 \\
\hline
\end{tabular}

${ }^{1}$ Source: Authors' calculations based on Comtrade database (UNSD, 2013) with World Integrated Trade Solution (WITS; http://wits.worldbank.org) software.

${ }^{2}$ Revealed comparative advantage index.

rates and thus longer durations of the $\mathrm{RCA}>1$ indices for the BEC 112. Among them are France and Germany, both with perfect survival over the 12-yr period. The case of Malta is distinct, as no BEC dairy group of products has been able to survive export competitiveness during the 12-yr period.

The equality of survival functions among the BEC dairy group of products using the Wilcoxon nonparametric test shows that, except for Malta, the hypothesis of equality of survival function across the BEC dairy group of products can be rejected at the $1 \%$ level of significance. Therefore, except for Malta, the survival functions for the RCA $>1$ differ significantly between the BEC dairy groups of products for the other EU-27 countries.

These mixed-export specialization patterns in differentiated dairy products by the EU-27 countries suggest the importance of not only natural factor endowments and structural determinants in vertical dairy export supply chains, but also of innovation for more sophisticated and higher valued types of dairy products, which require more complex knowledge, more technological facilities, and more dynamic entrepreneurial business and international marketing activities for international dairy sector competitiveness and the long-term duration of revealed comparative advantages.

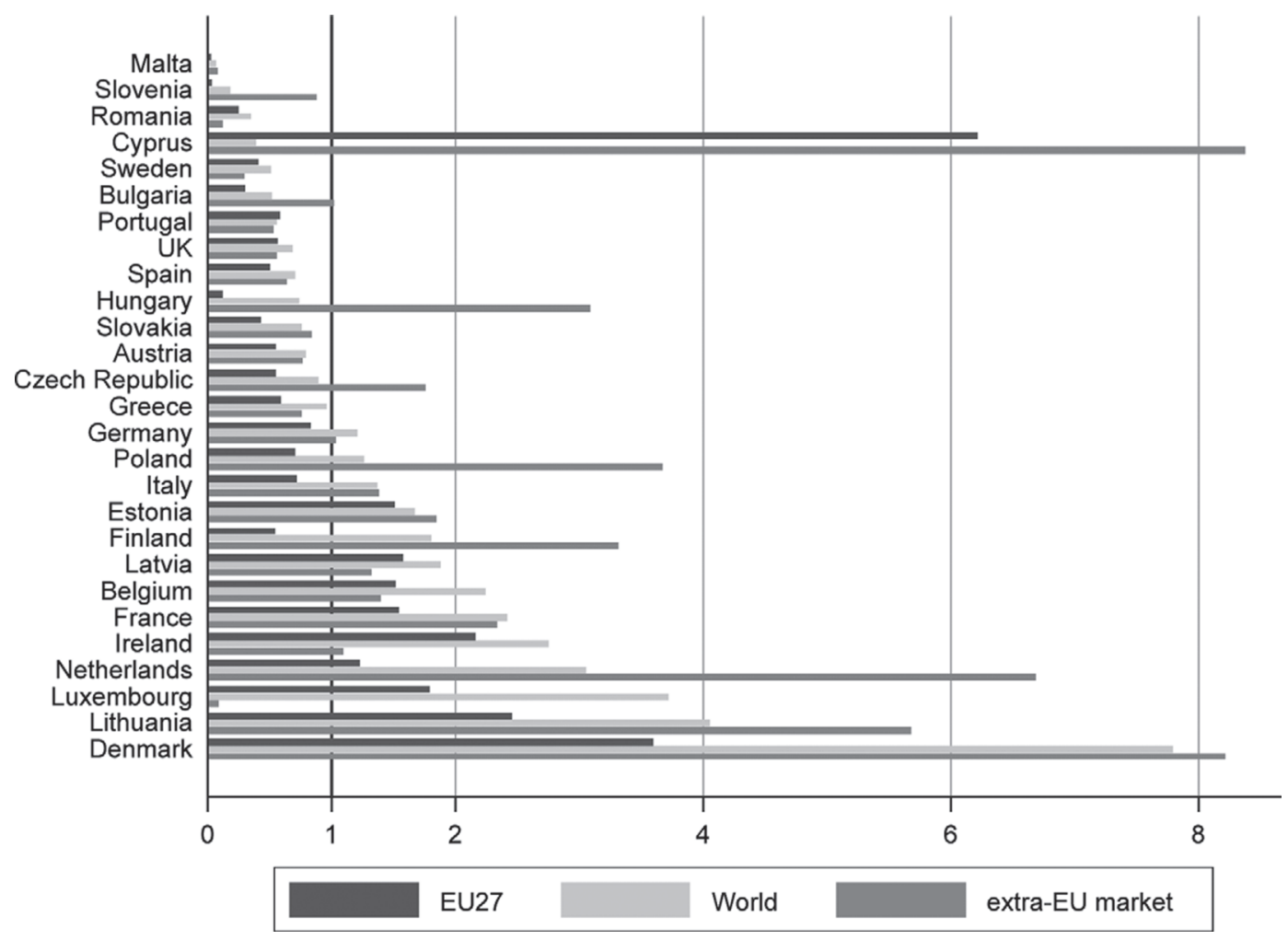

Figure 5. Mean values of revealed comparative advantage (RCA) indices for the Broad Economic Classification (BEC) 122: processed dairy and dairy products intended for final consumption in households in the EU-27 countries from 2000 to 2011. EU27 = intra-European Union (EU) market, and World = intra-EU and extra-EU markets. Source: Authors' calculations based on Comtrade database (UNSD, 2013) with World Integrated Trade Solution (WITS; http://wits.worldbank.org) software. 
Table 2. Mobility $\left(M_{1}\right)$ of revealed comparative advantage (RCA) indices from 2000 to 2011 in the world, intra-European Union (EU), and extra-EU markets ${ }^{1,2}$

\begin{tabular}{|c|c|c|c|}
\hline Country & World & Intra-EU & Extra-EU \\
\hline Austria & 0.1673 & 0.3198 & 0.1805 \\
\hline Belgium & 0.1884 & 0.2669 & 0.1691 \\
\hline Bulgaria & 0.2584 & 0.4281 & 0.3377 \\
\hline Cyprus & 0.4062 & 0.4426 & 0.4467 \\
\hline Czech Republic & 0.2832 & 0.4021 & 0.2533 \\
\hline Denmark & 0.2212 & 0.3799 & 0.2717 \\
\hline Estonia & 0.2692 & 0.3891 & 0.4218 \\
\hline Finland & 0.1596 & 0.3376 & 0.2277 \\
\hline France & 0.2439 & 0.2645 & 0.2679 \\
\hline Germany & 0.1854 & 0.3291 & 0.1457 \\
\hline Greece & 0.2994 & 0.4979 & 0.3545 \\
\hline Hungary & 0.3211 & 0.5261 & 0.4423 \\
\hline Ireland & 0.2089 & 0.2276 & 0.2089 \\
\hline Italy & 0.1920 & 0.1873 & 0.0439 \\
\hline Latvia & 0.3909 & 0.5824 & 0.5366 \\
\hline Lithuania & 0.2413 & 0.4563 & 0.3986 \\
\hline Luxembourg & 0.1537 & 0.2146 & 0.2607 \\
\hline Malta & 1.0000 & 0.9138 & 0.9138 \\
\hline Netherlands & 0.1923 & 0.2504 & 0.2437 \\
\hline Poland & 0.3897 & 0.5988 & 0.32 \\
\hline Portugal & 0.2602 & 0.2932 & 0.2395 \\
\hline Romania & 0.2239 & 0.5568 & 0.5428 \\
\hline Slovakia & 0.2880 & 0.5744 & 0.5063 \\
\hline Slovenia & 0.2626 & 0.2782 & 0.2569 \\
\hline Spain & 0.2927 & 0.2851 & 0.2601 \\
\hline Sweden & 0.4203 & 0.6616 & 0.3441 \\
\hline United Kingdom & 0.2750 & 0.3501 & 0.2916 \\
\hline
\end{tabular}

${ }^{1}$ Source: Authors' calculations based on Comtrade database (UNSD, 2013) with World Integrated Trade Solution (WITS; http://wits.worldbank.org) software.

${ }^{2} M_{1}$ can take values $0<M_{1}<2$.

The survival rates were particularly high for France, Denmark, and the Netherlands among the old EU-15 member states and for Poland and Latvia among the new EU-12 member states, indicating a longer duration of export competitiveness for differentiated dairy groups of products. Even among relatively high duration of export competitiveness in yr 12 (2011); for example, for France and the Netherlands, significant differences were found across groups of dairy products according to the level of milk processing in their probability of RCA $>1$ survival in intra-EU and particularly extraEU markets.

\section{DISCUSSION}

We identified 2 main groups of EU-27 countries on the basis of their export competitiveness on global markets for groups of dairy of products according to the level of milk processing. First, the group of the EU-27 countries with strong RCA $>1$ dairy products revealed a comparative advantage on global markets at the aggregated dairy level and according to the BEC dairy products. This group consisted of Belgium, Denmark, France, Ireland, and the Netherlands from the EU-15 member states and the Baltic States (Estonia, Latvia, and Lithuania) and Poland from the EU-12 member states.
Second, the group of the EU-27 countries with weak dairy sectors showed comparative advantages or revealed comparative disadvantages on global markets. These were Sweden and the UK from the EU-15 member states, and Malta and Romania from the EU-12 member states.

In addition, some countries had revealed comparative advantages for niche dairy products, such as Greece and Spain for the BEC 112, or only temporary export competitiveness for individual years. In some of the EU27 countries, changes in the evolution of export competitiveness can be explained by fluctuations of dairy export values from year to year. In addition, some dairy products from some EU-27 countries are not exported on global markets each year, which is in line with the trade duration literature at the highly disaggregated dairy export data level.

To analyze the role of market segments on dairy products export competitiveness, the Spearman rank correlation coefficients for each market segments was calculated between 3 indicators: mean RCA values, $M_{1}$ indices, and Kaplan-Meier survival rates in the final analyzed year (2011; Table 4). First, the positive relationship between mean RCA values and Kaplan-Meier survival rates for each of the market segments was stronger for extra-EU than for intra-EU dairy exports. This 


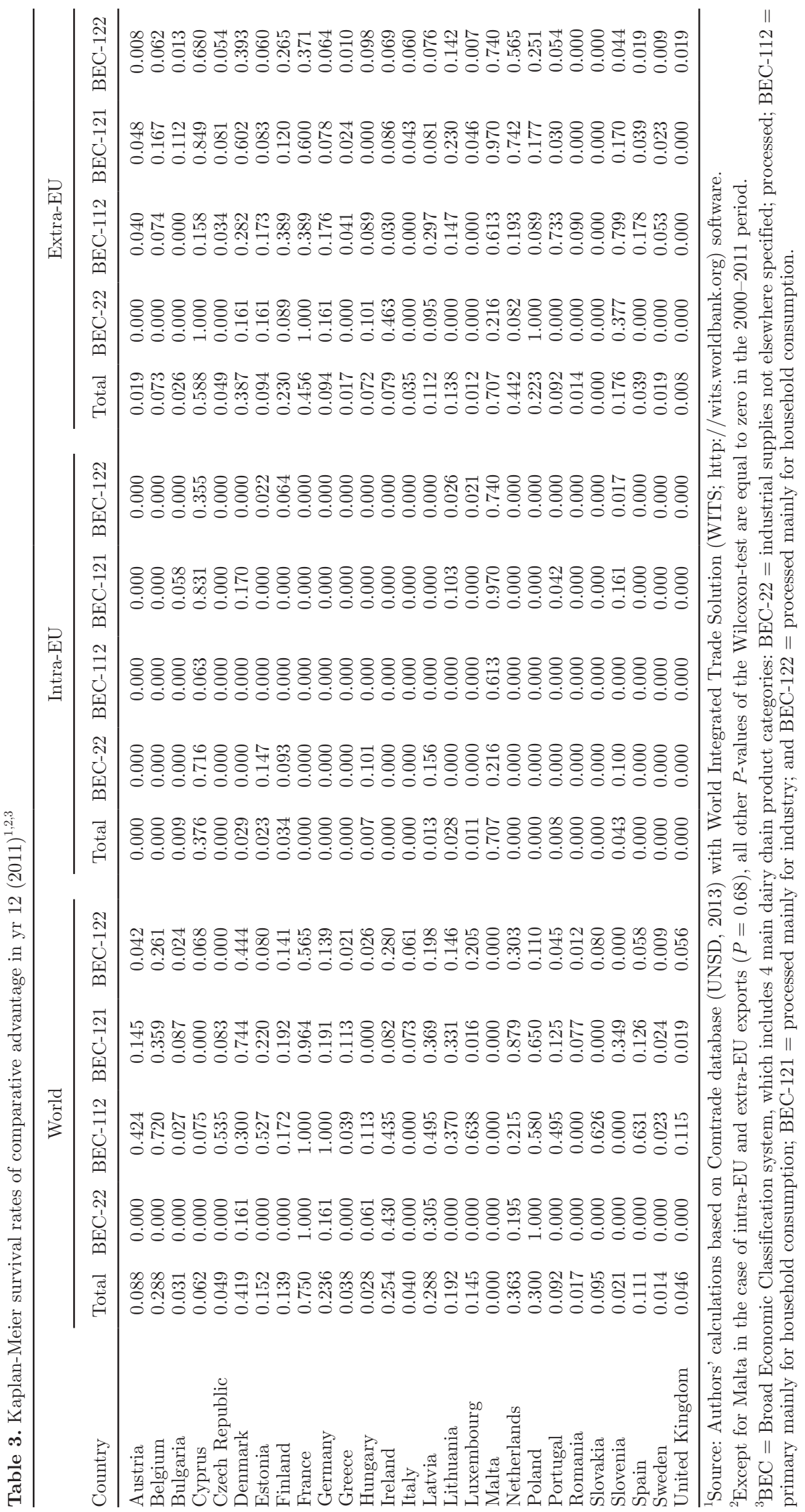


suggests rather strong and long-term EU dairy export competitiveness in each market segment, particularly extra-EU markets. Second, the negative relationship between mobility $M_{1}$ indices and mean RCA values for each market segment confirmed a strong relationship between higher mobility and weak export competitiveness. Finally, the results were mixed for the relationship between mobility $M_{1}$ indices and Kaplan-Meier survival rates. The relationship was slightly positive for dairy export competiveness on intra-EU markets but negative on extra-EU markets. These relatively weak relationships suggest neither a strong relationship between mobility $M_{1}$ indices and Kaplan-Meier survival rates nor substantial differences between the market segments.

The importance of the research results is found in the implications for dairy chain management and policy. Dairy product chain export specialization in differentiated dairy products by most of the EU-27 countries implies the importance of exploiting both the economies of scale of comparative advantages of rich natural factors of production and dairy infrastructure to boost cost-competitive dairy products and dairy product diversification into varieties for consumers on global markets. The prevailing export competitive strategy by the EU-27 countries is based on dairy product chain diversification with associated quality and marketing approaches, including brand name development. This is typical for monopolistic competition with product quality and product varieties as crucial managerial and supply chain management implications important for the dairy business, commercial trading, and export supply chain management.

The applied RCA approach with the duration analysis is also essential for dairy science analysis. As argued by Roupas (2008), advantages derived from the use of predictive modeling methodologies of processes through the entire dairy supply chain can provide bet- ter understanding of the complexities of interactions in differentiated dairy products. The improved information system and new knowledge can contribute to better understanding of dairy product chain export competitiveness as significant for decision-making processes in increased efficiency and quality demanded by global markets, which can result in associated economic benefits for dairy producers and other horizontally and vertically integrated dairy chain participants and stakeholders. It is important to strengthen dairy industry integration across the entire supply chain from on-farm practices, processing milk, and marketing to consumers for a competitive dairy industry in differentiated dairy products on global markets (see also Augustin et al., 2013).

Dairy sector policy implications are seen in the support of enabling macro-economic and the dairy sector environment, thereby strengthening global competitiveness and export specialization toward competitive products in the global dairy chain. The process of further dairy market deregulation, the reduction and abolition of dairy export subsidies and dairy production quotas, and the roles of different public support measures are more likely to be a process driven by World Trade Organization global talks on market- and government-support measures. However, in the long term, the sustainable economic, social, and environmental development of the dairy sector largely depends on the role of revealed comparative advantages and the differentiated dairy products chains' abilities to survive in global market competition.

The role of export competitiveness cannot be neglected in dairy chain management and in policy formulation. The promotion of competitive dairy export and its long-term duration are crucial lessons learnt and message derived from the RCA empirical application with the duration analysis for the EU-27 countries. The most export competitive EU-27 countries on global

Table 4. Spearman correlation coefficients between indicators and summary of findings about the role of market segments on dairy products export competitiveness ${ }^{1,2}$

\begin{tabular}{|c|c|c|c|}
\hline & Kaplan-Meier & $M_{1}$ & RCA mean \\
\hline \multicolumn{4}{|l|}{ World } \\
\hline Kaplan-Meier & 1.0000 & & \\
\hline$M_{1}$ & -0.3694 & 1.0000 & \\
\hline RCA mean & 0.8168 & -0.3352 & 1.0000 \\
\hline \multicolumn{4}{|l|}{ Intra-EU } \\
\hline Kaplan-Meier & 1.0000 & & \\
\hline$M_{1}$ & 0.0262 & 1.0000 & \\
\hline RCA mean & 0.2954 & -0.1364 & 1.0000 \\
\hline \multicolumn{4}{|l|}{ Extra-EU } \\
\hline Kaplan-Meier & 1.0000 & & \\
\hline$M_{1}$ & -0.0006 & 1.0000 & \\
\hline RCA mean & 0.6770 & -0.0324 & 1.0000 \\
\hline
\end{tabular}


dairy chain markets are competitive in each or most stages of the dairy sector export supply chain, according to the level of milk product processing and marketing. In contrast, the EU-27 countries with uncompetitive exports are not competitive in all or most stages of the dairy sector export chain, regardless of the level of milk processing. This implies 2 main messages for dairy supply chain management. First, it is important to ensure and strengthen synergies in export supply chain efficiency improvements in each of the vertical stages of milk production, milk processing and dairy product marketing to utilize technological and other advantages from economies of scale and organizational advantages. Second, the important competitiveness and survival strategy measures should be oriented toward dairy product chain diversification from product varieties and different qualities, brand name development, and other dairy trading and marketing activities. Future research must identify strengths and weaknesses as well as threats and opportunities for dairy product chain export competitiveness on the global markets. Other issues for future research include lessons learned from case studies of successful EU-27 countries strengthening export competitiveness in milk production, milk processing, and dairy product marketing and promotion activities on global dairy markets.

To summarize, for the EU-27 countries, the more competitive they are in dairy exports, the greater the probability of long-term export competitiveness survival in intra-EU and extra-EU dairy exports; concurrently, the larger the mobility in export competitiveness of a country, the less export competitive in intra-EU and extra-EU dairy exports it is.

\section{CONCLUSIONS}

Our results indicate that the most export-competitive EU-27 countries on global dairy chain markets are competitive in each or most stages of the dairy sector export supply chain, according to the level of milk product processing and marketing. In contrast, the EU-27 countries with uncompetitive exports are not competitive in all or most stages of the dairy sector export chain, regardless of the level of milk processing. This implies 2 main messages for dairy supply chain management. First, it is important to ensure and strengthen synergies in export supply chain efficiency improvements in each of the vertical stages of milk production, milk processing, and dairy product marketing to utilize technological and other advantages from economies of scale and organizational advantages. Second, the important competitiveness and survival strategy measures should be oriented toward dairy product chain diversification from product varieties and different qualities, brand name development, and other dairy trading and marketing activities.

\section{ACKNOWLEDGMENTS}

This publication was generated as part of the COMPETE Project, Grant Agreement No. 312029 (http:// www.compete-project.eu/), with financial support from the European Community under the 7th Framework Programme. The authors gratefully acknowledge the useful suggestions and comments made by the two anonymous journal reviewers.

\section{REFERENCES}

Augustin, M. A., P. Udabage, P. Juliano, and P. T. Clarke. 2013. Towards a more sustainable dairy industry: Integration across the farm-factory interface and the dairy factory of the future. Int. Dairy J. 31:2-11.

Bailey, K. W. 2004. A multiple-component analysis of US dairy trade. J. Dairy Sci. 87:1934-1944

Balassa, B. 1965. Trade liberalization and revealed comparative advantage. Manchester Sch. Econ. Soc. Stud. 33:99-123.

Barney, J. P., and T. R. Smith. 1998. How local dairy communities can compete in the global marketplace. J. Dairy Sci. 81:1762-1768.

Bojnec, S., and I. Fertö. 2008. Dairy trade competitiveness: Crucial role of processed products. Milchwissenschaft 63:434-438.

Buxton, B. M., and G. E. Frick. 1976. Can the United States compete with dairy exporting nations? J. Dairy Sci. 59:1184-1192.

Cecchinato, A. 2013. Survival analysis as a statistical methodology for analyzing factors that affect milk coagulation time in HolsteinFriesian and Brown Swiss cows. J. Dairy Sci. 96:5556-5564.

Cleves, M. A., W. W. Gould, and R. G. Gutierez. 2004. An Introduction to Survival Analysis Using STATA. Stata Press, College Station, TX.

Costinot, A., D. Donaldson, and I. Komunjer. 2012. What goods do countries trade? A quantitative exploration of Ricardo's ideas. Rev. Econ. Stud. 79:581-608.

De Benedictis, L., and M. Tamberi. 2004. Overall specialization empirics: Techniques and applications. Open Econ. Rev. 15:323-346.

Drescher, K., and O. Maurer. 1999. Competitiveness in the European dairy industries. Agribusiness 15:163-177.

Dunnett, G. S. 1933. The trend of production and trade in milk and milk products. J. Dairy Res. 4:317-320.

FAO. 2013. FAOSTAT Trade database. Food and Agriculture Organization of the United Nations, Rome, Italy.

Fertő, I., and L. J. Hubbard. 2003. Revealed comparative advantage and competitiveness in Hungarian agri-food sectors. World Econ. $26: 247-259$.

Hockmann, V. H., H. Saale, and M. Ramanovich. 2007. Competitiveness of Belarus' dairy sector source. Berichte über Landwirtschaft $85: 300-328$.

Kirner, R. 2005. International competitiveness of Austrian milk production-Results from the IFCN network. Bodenkultur 54:221229.

Leromain, E., and G. Orefice. 2013. New revealed comparative advantage index: Dataset and empirical distribution. Centre d'études prospectives et d'informations internationales (CEPII) Working Paper 2013-20. Accessed Mar. 25, 2014. http://www.cepii.fr/ PDF_PUB/wp/2013/wp2013-20.pdf.

Liebe, A., and D. Schams. 1998. Growth factors in milk: Interrelationships with somatic cell count. J. Dairy Res. 65:93-100.

Losinger, W. C. 2005. Economic impact of reduced milk production associated with Johne's disease on dairy operations in the USA. J. Dairy Res. 72:425-432. 
Marchant, M. A., and S. A. Neff. 1995. Interaction of United States and European Community dairy policies through the international market. J. Dairy Sci. 78:1191-1198.

Novakovic, A. M., and R. L. Thompson. 1978. Dairy imports: How serious a threat? J. Dairy Sci. 61:1627-1633.

Pinior, B., M. Konschake, U. Platz, H. D. Thiele, B. Petersen, F. J. Conraths, and T. Selhorst. 2012. The trade network in the dairy industry and its implication for the spread of contamination. J. Dairy Sci. 95:6351-6361.

Roupas, P. 2008. Predictive modelling of dairy manufacturing processes. Int. Dairy J. 18:741-753.

Shorrocks, A. 1978. The measurement of mobility. Econometrica 46:1013-1024.

Stukenberg, D., and D. Blayney. 2006. Major advances in milk marketing: Government and industry consolidation. J. Dairy Sci. 89:1195-1206.
Suzuki, N., and H. M. Kaiser. 2005. Impacts of the Doha Round framework agreements on dairy policies. J. Dairy Sci. 88:1901-1908.

Tacken, G. M. L., M. Banse, A. Batowska, C. Gardebroek, K. N. Turi, J. H. M. Wijnands, and K. J. Poppe. 2009. Competitiveness of the EU Dairy Industry. CAB Direct, Wallingford, UK.

UNSD (United Nations Statistical Division). 2013. Commodity Trade Database (Comtrade), available through World Bank's World Integrated Trade Solution (WITS) software: http://wits.worldbank. org.

Van der Straeten, B., J. Buysse, G. Van Huylenbroeck, and L. Lauwers. 2009. Impact of policy-induced structural change on milk quality: Evidence from the Flemish dairy sector. J. Dairy Res. $76: 234-240$.

Vollrath, T. L. 1991. A theoretical evaluation of alternative trade intensity measures of revealed comparative advantage. Weltwirtsch. Arch. 130:263-279.

\section{APPENDIX}

Table A1. Concordance between the Broad Economic Classification (BEC) system and the 6-digit World Customs Organization's Harmonized System (HS-6) for dairy products

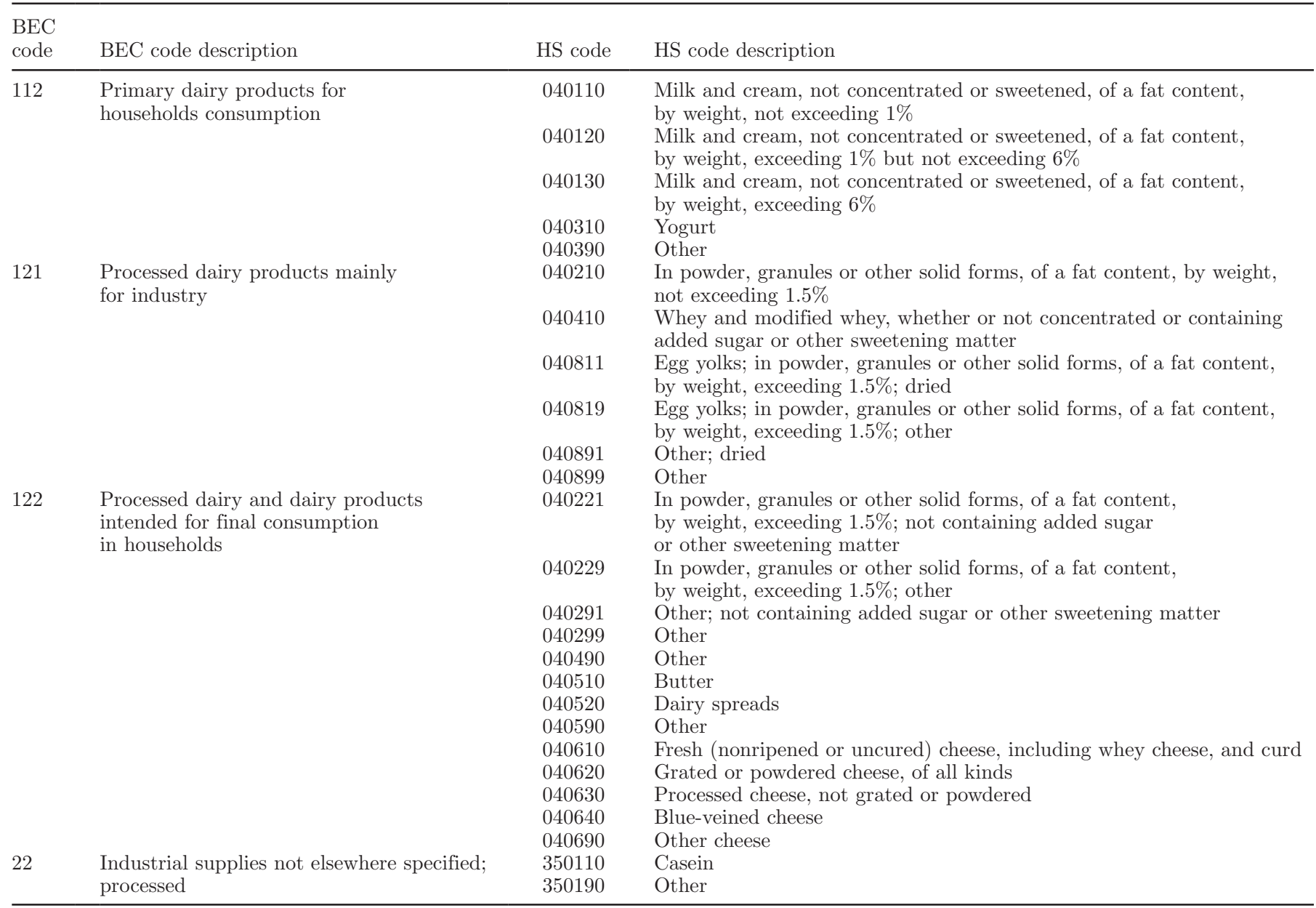

${ }^{1}$ Source: UNSD (2013). 